\title{
Interchangeable core and cavity plates for two-plate family injection mould
}

\author{
M. A. M. Ali ${ }^{1,2 *}$, N. Idayu ${ }^{1}$, Z. Abdullah ${ }^{1}$, M. H. A. Bakar ${ }^{1,2}$, S. Sivarao', M. S. A. \\ Aziz $^{1,2}$ and A. Abdullah ${ }^{1,2}$ \\ ${ }^{1}$ Faculty of Manufacturing Engineering, Universiti Teknikal Malaysia Melaka (UTeM), \\ 76100 Durian Tunggal, Melaka, Malaysia \\ *Email: mohdamran@utem.edu.my \\ Phone: +6063316979; Fax: +6063316411 \\ ${ }^{2}$ Precision Machining Group (PMG), Universiti Teknikal Malaysia Melaka (UTeM), \\ 76100 Durian Tunggal, Melaka, Malaysia
}

\begin{abstract}
This study modified a two-plate family plastic injection mould to become interchangeable by changing the core and cavity plates using an existing mould base. The plastic parts produced in the modified two-plate family plastic injection mould included tensile, hardness, impact and flexural test specimens. The cavities of the plastic parts were machined at the parting surface of core plate. Meanwhile, the feeding systems including runner and gate system were machined at the cavity plate to ensure molten plastic can be injected in the cavity area. Various factors have been considered during the designing and fabricating process. This is to ensure the process of assembly between mould plate and standard mould parts can be done perfectly. The plastic parts in the family mould were successfully injected after mould was completed assembled and mould trial was performed. The plastic parts which had been ejected from the family injection mould are purposely produced for future research to study the mechanical properties of plastic materials.
\end{abstract}

Keywords: Family mould; plastic product; interchangeable mould; mould design

\section{INTRODUCTION}

The plastic injection mould industry is considered as an economic sector which produces the intricate plastic parts. Usually, plastic parts are produced after they have been injected into a steel mould. In mould manufacturing, machining activities play a large part during the mould fabrication $[1,2]$. In mould design and mould analysis, modern design and advanced facilities such as computer aided manufacturing (CADCAM) software and computer numerical control (CNC) machines can help mould designers by reducing the risk and time delay. With the help of these facilities, it will help the mould designers to model and prepare numerical control (NC) code for CNC machines and check the alignment of a set of assembly of mould. There are two types of tool movement positioning such as absolute and incremental positioning while preparing the NC code. The usual method used is absolute positioning with a fixed zero or origin as a reference point. Meanwhile, incremental positioning is also sometimes used with the previous point as the reference for the next movement $[3,4]$. In fabricating an interchangeable mould plate, two main manufacturing processes are involved. The two main processes are electrical discharge machine (EDM) die sinking $[5,6]$ and high speed milling (HSM) 
technology $[7,8]$. CNC milling using high speed milling (HSM) technology is always preferred to machine mould due to its flexibility. In machining, feed cutting direction is taken into consideration before proceeding to the machining process [9-11]. Feed cutting direction of the milling process can be divided into two methods; either conventional or climb milling. In conventional milling, the cutting edge moves upward as the workpiece is being fed into the cutter or the workpiece is fed against the rotation of the cutter. The conventional milling chip has no thickness at the beginning but builds in size toward the exit of the cutter. This method is recommended on materials with a hard outer scale such as cast steels or forgings. For climb milling, the cutter attempts to climb onto the workpiece or the workpiece is fed with the rotation of the cutter. This method is desirable in most cases because it takes less horsepower to cut in this fashion.

According to Rao [12], milling parameters include depth of cut, cutting speed and feed rate. Depth of cut (DOC) is the thickness of material removed by one pass of the cutting tool. It needs to be determined first before machining. The second milling parameter is cutting speed. Cutting speed $(\mathrm{N})$ is defined as the rate or speed in which the material moves past the cutting edge of the tool. It is controlled primarily but not exclusively by the hardness of the material. Usually, harder materials generate more heat because of the difficulty in penetrating the harder surfaces. The cutting speed is calculated in rpm as shown in Eq. (1) where CS is the linear cutting speed on surface in feet per minute (fpm) or metre per minute. $\mathrm{D}$ is diameter in inches or $\mathrm{mm}$ of the tool.

$$
N(\mathrm{rpm})=\frac{C S \times 1000}{\pi D}
$$

Another milling parameter that should be considered is the feed rate. Feed rate $(\mathrm{F})$ is the velocity at which the cutter is fed or advanced against the workpiece. In milling, it is expressed in units of inches per minute or millimetres per minute with considerations of how many teeth or flutes the cutter has, then determining what that means for each tooth. To calculate the feed rate for a mill cut, Eq. (2) is used. R is the chip load per tooth and $\mathrm{T}$ is the number of teeth on the cutter. RPM is the spindle speed in revolutions per minute.

$$
F=R \times T \times R P M
$$

This interchangeable core and cavity plates involved fabrication of family mould. Family mould always consists of different sizes of plastic parts. Due to its geometrical shape being different, analysis software are needed to analyse molten flow filling in the cavity area. Furthermore, moldflow software is always used to determine the defects of the injection mould part such as part weight, weldline, sink mark, shrinkage and warpage [13-15]. Moldflow software has the capability to simulate the plastic material inside the cavity area from the feeding system. Therefore, some researchers have performed mould analysis using the autodesk moldflow insight (AMI) software in order to obtain high quality product by finding the most optimum process parameters. Optimisation of parameters reduces operation costs through shortening the time for design and production $[3,16,17]$. Furthermore, family mould can reduce production costs where in a single shot, it can produce many parts at one time. However, each product has different volumes and shapes since each product is not similar to each other. Therefore, controlling the quality of each product is very crucial. To overcome this problem, various methods have been applied such as by optimising the feeding system, controlling the injection parameters, 
and adding flow path in the core area [18, 19]. Interchangeable insert mould is the best method applied for producing new plastic parts by using existing mould base where the cost of buying a new mould base can be avoided. King and Tansey [20] used rapid prototyping technology where interchangeable insert mould was made from plastic materials. This rapid prototyping or additive manufacturing has become more popular for making interchangeable core insert for a small volume or short run production [21]. This study used interchangeable insert where the core and cavity plates were designed, machined and assembled to the mould base. The designing process of the core and cavity plates used the CATIA software and machined by using the CNC milling machine. The existing mould base was used by replacing new core and cavity plates. This interchangeable mould can reduce manufacturing cost through replacing these two mould plates, i.e., core and cavity plates.

\section{METHODS AND MATERIALS}

\section{Fabrication Planning}

Various processes such as plastic parts design, mould design, core and cavity plates design, machining and assembly process were involved for producing the plastic parts in this study. The core and cavity plates removal is shown in Figure 1. Firstly, at the initial stage, the plastic parts were designed using the CATIA software version V5R19. Before the mould machining process started, the plastic parts of the family mould were simulated by using Autodesk Simulation Mouldflow ${ }^{\circledR}$ Insight software for the selection of the best runner layout.

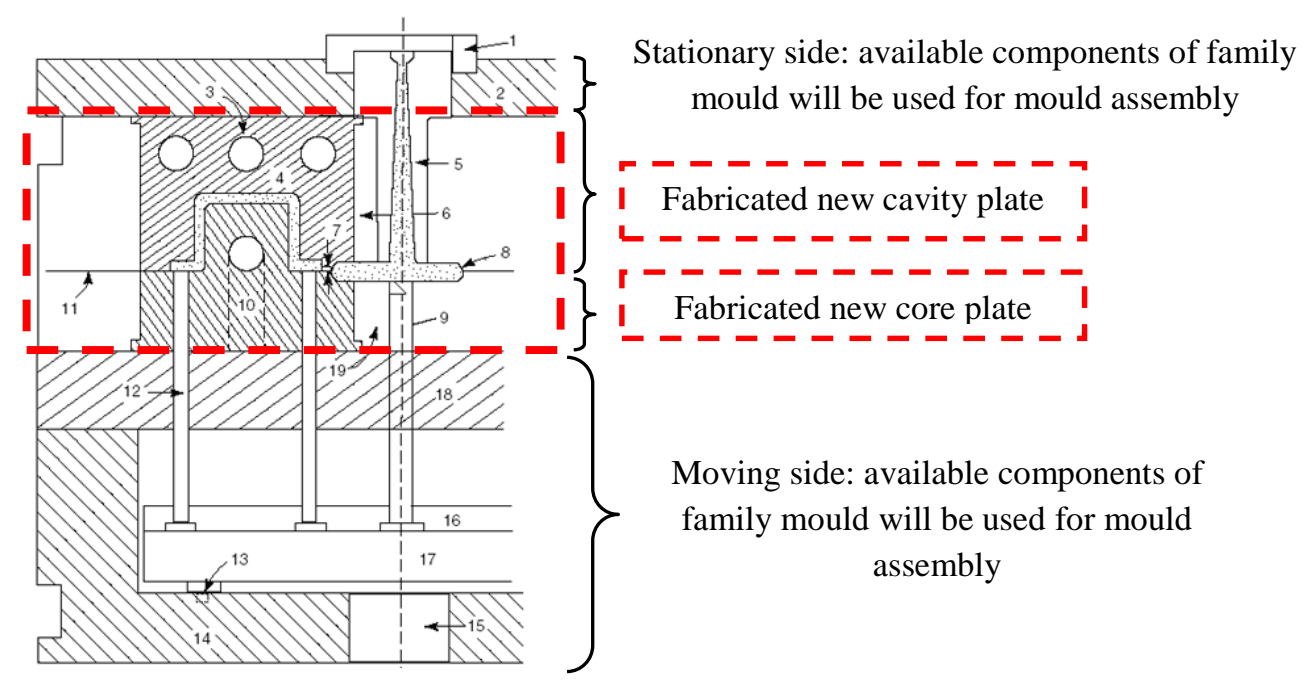

Figure 1. Interchangeable core and cavity plates of injection mould.

From our previous investigation [22], it was found that runner linear layout was selected because it showed a faster filing time of 1.1873 second as compared to the runner star layout. Moreover, warpage and shrinkage of linear layout were lower than the star layout at $0.0361 \mathrm{~mm}$ and $0.78 \%$ respectively. Therefore. The runner linear layout was selected because it showed better results when compared to the runner star layout. After that, the mould core plate and cavity plate were designed by using AutoCAD software. Then, the machining process was performed using CNC milling to machine the core and cavity plates of the mould. After completing the machining process of family injection mould, the mould base was assembled. At the final stage, mould base was clamped inside 
the injection moulding machine ARBURG 420C and mould trial was performed. Figure 2 shows the original core and cavity plates of the injection mould where the core and cavity plates will be removed and changed by the new plates.

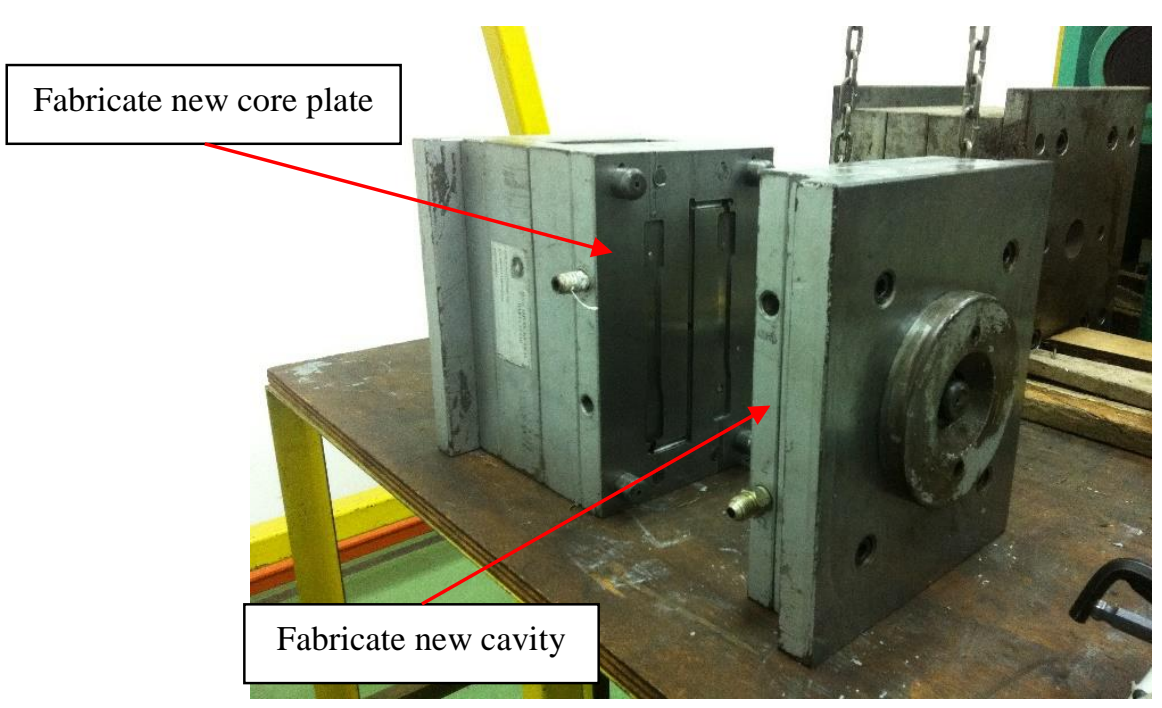

Figure 2. Original core and cavity plates of injection mould.

\section{RESULTS AND DISCUSSION}

\section{Plastic Parts Design}

Figure 3 shows the four mechanical test specimens in this study. The mechanical test specimens were designed and consisted of tensile (ASTM D638), hardness (ASTM D785), impact (ASTM D256) and flexural test specimens (ASTM D790) [23]. This mould is called as the family mould because there are four different parts that need to be produced. CATIA V5R19 software was used to design the family plastic parts.

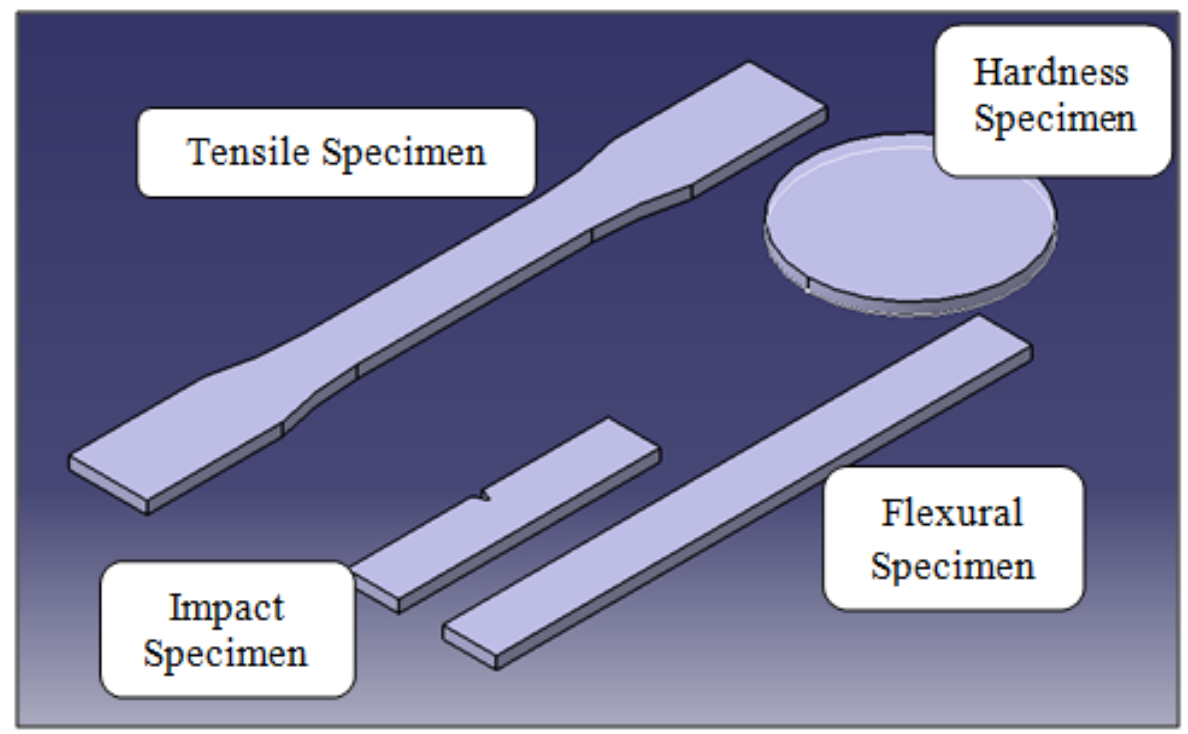

Figure 3. Plastic parts drawn by using the CATIA software. 


\section{Mould Design}

A two-plate mould was chosen for this study. Only the core and cavity plates needed to be designed and machined. The mould base size selected was $255 \mathrm{~mm}$ x $170 \mathrm{~mm}$. Mild steel was chosen for this study because it does not involve long production runs even though the injected parts have a similar quality as mould made from pre-hardened steel [24]. It is only for research purposes where the performance of mould is not as critical as in an industrial application. Mild steel is a low-carbon steel which contains approximately $0.05 \%-0.32 \%$ carbon, making it malleable and ductile for easy machining compared to pre-hardened steel [25]. The mould base was designed by using AutoCAD software. The first mould base plate designed was the core plate as shown in Figure 4(a). The core plate with $255 \mathrm{~mm} \times 170 \mathrm{~mm} \times 25 \mathrm{~mm}$ has been used. Runner linear layout was implemented in the mould feeding system. Cooling system was also considered when deciding the location of the ejector hole of this plate. Ejector holes were designed according to the location of the family mould parts. In addition, the core plate was designed to fit with the existing backup and ejector plate. The mould core plate was marked at one side for machining reference. It was located by indicating the $\mathrm{x}$-axis and $\mathrm{y}$-axis. The drawing was divided into two views which were the top view and section view. In the engineering 2D drawing, the most important method was to locate the origin of the dimensioning system. The dimensioning system always begins from $\mathrm{x}$-axis and y-axis. Meanwhile, the section view shows the location and size of the water cooling system.
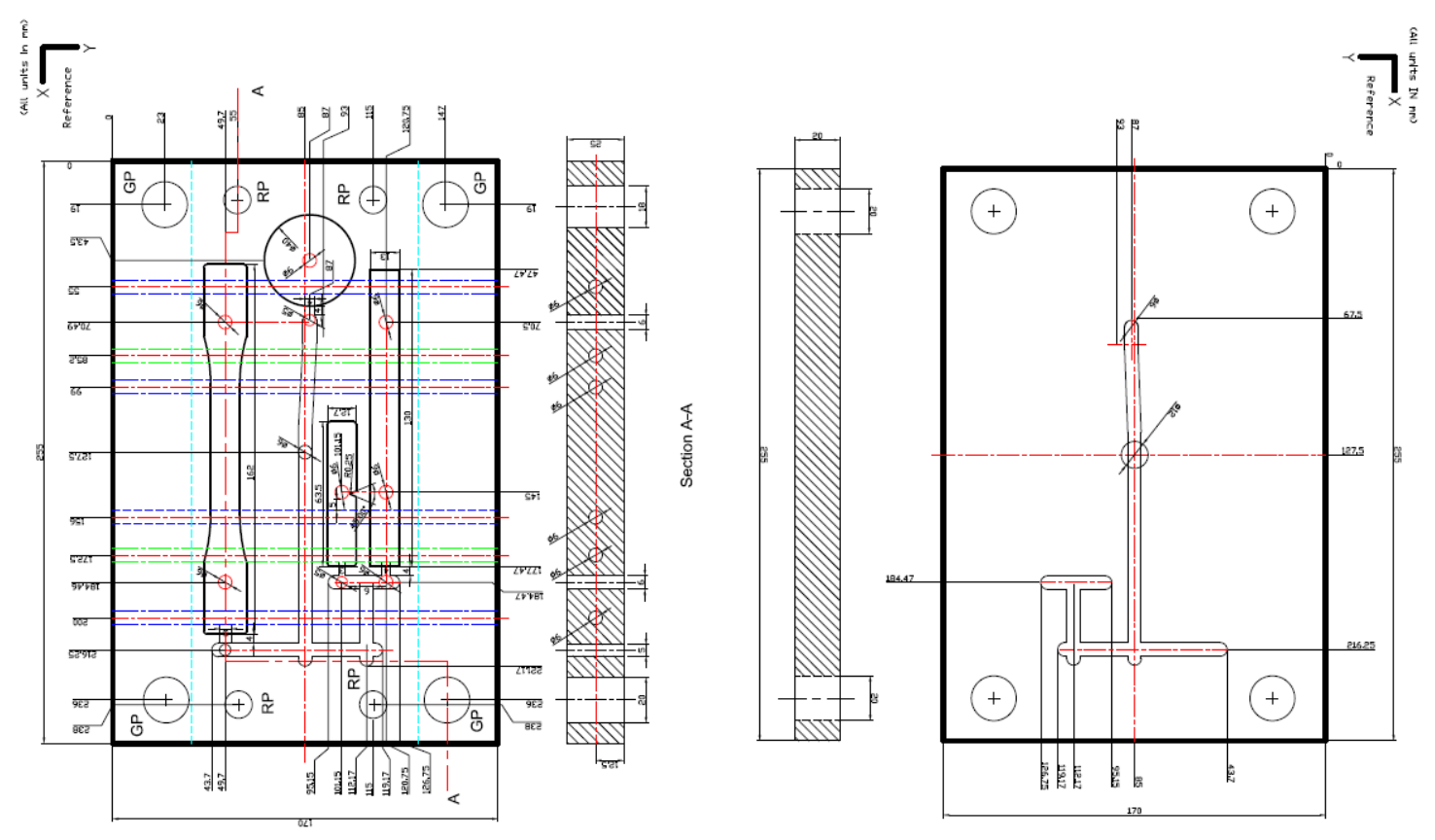

Figure 4. Engineering 2D drawing of the family mould (a) core plate (b) cavity plate.

Cavity plate consists of the runner system. Figure 4(b) shows the cavity plate size at $255 \mathrm{~mm} \times 170 \mathrm{~mm} \times 20 \mathrm{~mm}$. Runner system in this plate also followed the runner linear layout. The centre of the cavity plate had a small hole for the sprue bush where the location of the feeding system was located. The four holes at the corner of the cavity plate were guide pin holes where the guide pins were attached during assembly. 


\section{Mould Machining}

Machining process planning is the most important stage before any machining process is conducted. It is to ensure the machining flow is running smoothly with minimal error. Basically, the process planning is a checklist of important instruction that may contain a precaution flag that has to be taken before machining is done. After that, the CAD drawing was converted into G-Code by using EdgeCAM software and the code was stored in a storage device before transferred to the machine control unit. Next is the machining process for core plate and cavity plate. Haas CNC Milling machine was used to fabricate both the core and cavity plates. Table 1 and Table 2 show the machining process plan for both core and cavity plates respectively.

Table 1. Machining process planning of core plate.

\begin{tabular}{|c|c|c|c|}
\hline Operation & Part & $\begin{array}{c}\text { Operation } \\
\text { descriptions }\end{array}$ & $\begin{array}{c}\text { Tool/ } \\
\text { Equipment }\end{array}$ \\
\hline 1 & $\begin{array}{l}\text { Profiling: tensile, hardness, } \\
\text { impact and flexural }\end{array}$ & End mill & CNC Milling \\
\hline 2 & Runner & Ball mill $6 \mathrm{~mm}$ & CNC Milling \\
\hline 3 & $\begin{array}{l}\text { Ejector Pin Hole:(EP1, EP2, EP3, } \\
\text { EP5, EP7, EP8, EP9 \& EP10 ) }\end{array}$ & $\begin{array}{l}\text { Drilling } 5.8 \mathrm{~mm} \text { and } \\
\text { reaming } 6 \mathrm{~mm}\end{array}$ & CNC Milling \\
\hline 4 & $\begin{array}{l}\text { Ejector Pin Hole: (EP4, EP6 \& EP } \\
\text { 11) }\end{array}$ & $\begin{array}{l}\text { Drilling } 4.8 \mathrm{~mm} \text { and } \\
\text { reaming } 5 \mathrm{~mm}\end{array}$ & CNC Milling \\
\hline 5 & Return Pin (RP) Hole & $12 \mathrm{~mm}$ diameter & $\begin{array}{l}\text { Hand } \\
\text { Reamer }\end{array}$ \\
\hline 6 & $\begin{array}{l}\text { Guide Pin (GP) Hole: (GP } 3 \\
\text { \& GP4) }\end{array}$ & $\begin{array}{l}\text { Boring } 21 \mathrm{~mm} \\
\text { diameter }\end{array}$ & Table Drill \\
\hline
\end{tabular}

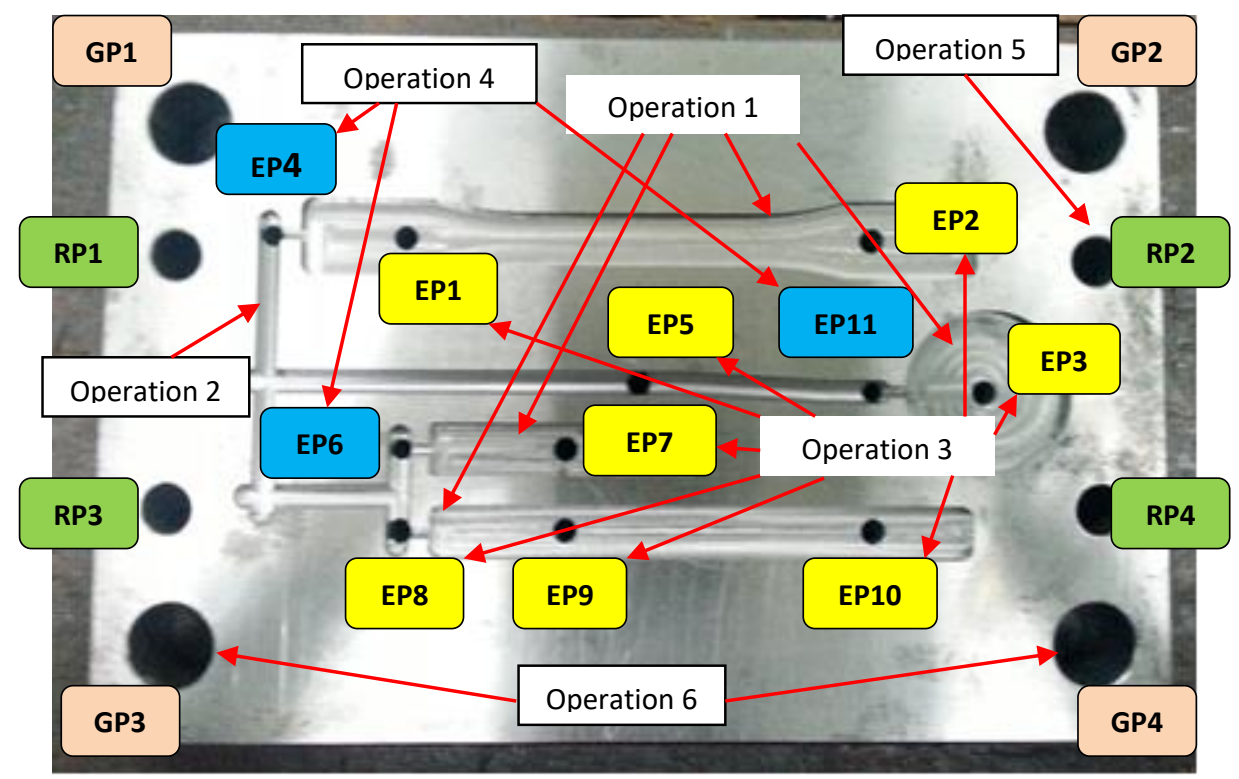

Figure 5 The core plate of the family mould

Figure 5 shows the new core plate for the family mould. After machining process of the mould was completed, the mould core plates were assembled with other mould plates; backup plate, ejector plate and bottom plate. All mould plates must be aligned, 
referring to the datum line or mould reference during the assembly process. Meanwhile, the new cavity plate was machined only at the runner system which is similar with the runner system at the core plate. After machining process of the cavity plate was completed, all the mould plates at the stationary side were assembled together.

Table 2. Machining process planning of cavity plate.

\begin{tabular}{cccc}
\hline Operation & Part & Operation descriptions & Tool/ Equipment \\
\hline 1 & Runner & Ball mill $6 \mathrm{~mm}$ & CNC Milling \\
\hline
\end{tabular}

\section{Mould Assembly}

Before the mould can produce the plastic parts, it first needs to be assembled with its base. There are two sections of the mould that is the stationary side and movable side. The stationary side is usually clamped to the injector nozzle where the molten material is supplied and the moving side is clamped to the hydraulic rod to activate the ejector pin once the plastic parts solidify. After the machining process of both plates was completed, the mould was then checked and cleaned from any debris by wiping it with a clean cloth. Air spray is recommended to blow the mould ejector hole due to the limitation of cloth to clean that part of the machining area. Different from cavity plate, core is the moving plate where the product is produced and ejected from the mould. The core is usually assembled with the base part such as backup plate, spacer bar, and ejector plate. Once the plate was paired with its base, both of the mould parts were joined to become one completed mould. Figure 6(a) and (b) show the core assembly and cavity assembly with the mould base. After the mould was mounted in the injection moulding machine ARBURG 420C with 80 tonnage, molten plastic was injected into the mould. Figure 6(c) shows the family plastic parts after ejection. It was found that the plastic parts produced a solid output with bubble built up in the sprue and runner but minimal on the flexural specimen. Therefore, optimisation of the injection moulding machine process parameters by using Moldflow simulation software is important to reduce defects on the plastic parts [26].
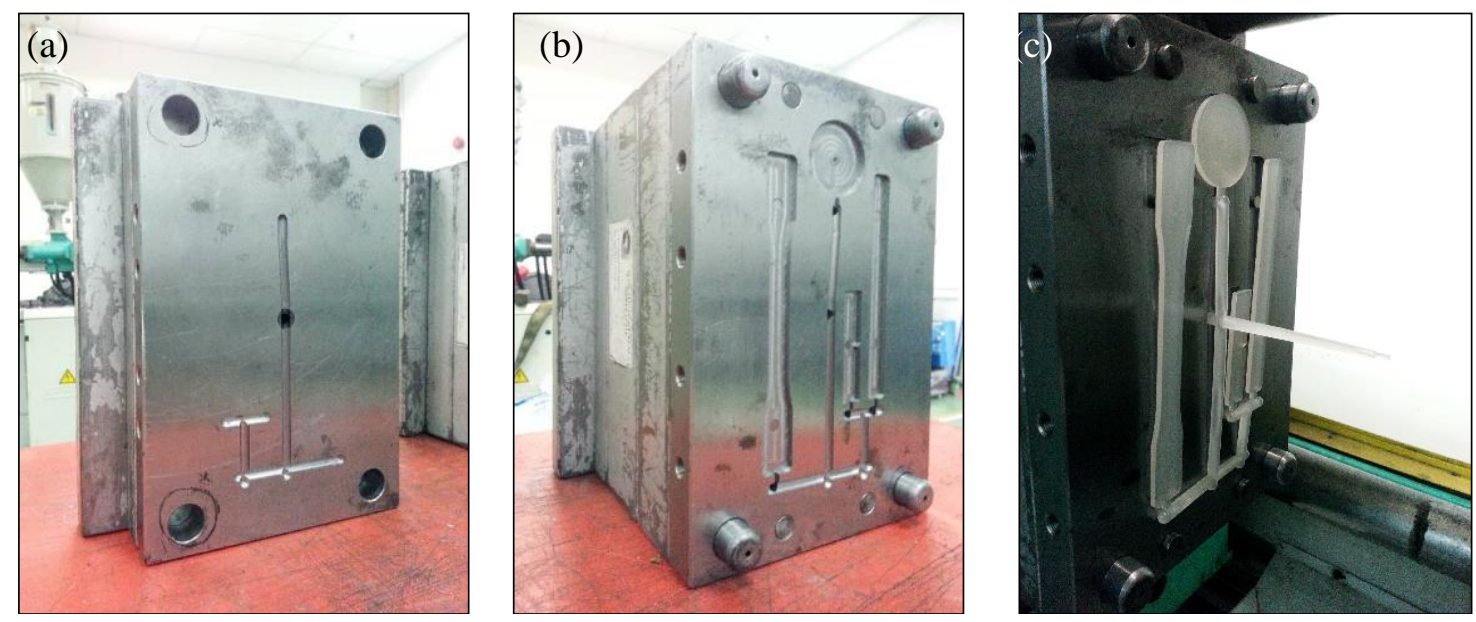

Figure 6. (a) Core assembly, (b) cavity assembly and (c) plastic parts.

The concept of Design for Manufacture and Assembly (DFMA) was applied in this project. DFMA is a methodology for optimising a new concept through an existing mould design in respect to manufacture and assembly by reducing the number of process needed [27] by eliminating excess machining process and manufacturing. The core plate, 
ejector base plate, and ejector retainer plate were clamped together when fabricating all ejector pins. Furthermore, the machining process at the cavity and feeding area was transferred directly from EdgeCAM software to HAAS CNC milling without manual programming. The assembly of mould was done by attaching the core and cavity plates directly without disassembling the whole mould components.

\section{CONCLUSIONS}

The interchangeable family injection mould was fabricated by replacing the core and cavity plates from an existing mould base. It consists of four different plastics parts which are tensile, hardness, impact, and flexural specimens. The mould was manufactured starting from mould design, fabrication and ended with the assembly stage. In the mould design stage, several factors were considered so that quality plastic parts can be produced. Determination of the suitable machining process planning before machining the mould was very important to avoid any mistakes from occurring. The assembling of the mould core and cavity plates with the mould base should be done with ease without any mismatch. By using interchangeable core and cavity plates, the existing mould base can be used, cost of buying a new mould base can be avoided, and fabrication time and cost can be reduced.

\section{ACKNOWLEDGEMENTS}

The authors would like to thank Universiti Teknikal Malaysia Melaka (UTeM) for providing facilities for this research to be conducted successfully. This research was funded under grant scheme RAGS/1/2014/TK01/FKP/B00075.

\section{REFERENCES}

[1] Rech J, Calvez CL, Dessoly MA. A new approach for the characterization of machinability-application to steels for plastic injection molds. Journal of Materials Processing Technology. 2004;152:66-70.

[2] Ajay KG. The complete technology book on plastic extrusion, moulding and moulds design: Asia Pacific Business Press Inc. Delhi. 2006.

[3] Najiha MS, Rahman MM, Kadirgama K, Noor MM, Ramasamy D. Multiobjective optimization of minimum quantity lubrication in end milling of aluminum alloy AA6061T6. International Journal of Automotive and Mechanical Engineering. 2015;12:3003-17.

[4] Rahman M, Wong YS, Zareena AR. Machinability of titanium alloys. International Journal Series C: Mechanical Systems, Machine Elements and Manufacturing. 2003;46:107-15.

[5] Ali MA, Samsul M, Hussein NIS, Rizal M, Izamshah R, Hadzley M, et al. The effect of EDM die-sinking parameters on material removal rate of beryllium copper using full factorial method. Middle-East Journal of Scientific Research. 2013;16:44-50.

[6] Mohanty S, Routara BC. A review on machining of metal matrix composites using nanoparticle mixed dielectric in electro-discharge machining. International Journal of Automotive and Mechanical Engineering. 2016;13:3518-39. 
[7] Izamshah R, Husna N, Hadzley M, Amran M, Shahir M, Amri M. Effects of cutter geometrical features on machining polyetheretherketones (PEEK) engineering plastic. Journal of Mechanical Engineering and Sciences. 2014;6:863-72.

[8] Bakar MHA, Abdullah RIR, Ali MAM, Kasim MS, Sulaiman MA, Ahmad SSN, et al. Surface integrity of LM6 aluminum metal matrix composite when machined with high speed steel and uncoated carbide cutting tools. Journal of Mechanical Engineering and Sciences. 2014;6:854-62.

[9] Kuzman K, Nardin B. Determination of manufacturing technologies in mould manufacturing. Journal of Materials Processing Technology. 2004;157:573-7.

[10] Razak NH, Rahman MM, Kadirgama K. Investigation of machined surface in endmilling operation of Hastelloy C-2000 using coated-carbide insert. Advanced Science Letters. 2012;13:300-5.

[11] Razak NH, Rahman MM, Kadirgama K. Cutting force and chip formation in end milling operation when machining nickel-based superalloy, Hastelloy C-2000. Journal of Mechanical Engineering and Sciences. 2017;11:2539-51.

[12] Rao RV. Advanced modeling and optimization of manufacturing processes: international research and development: Springer-Verlag, London; 2010.

[13] Amran MAM, Idayu N, Faizal KM, Sanusi M, Izamshah R, Shahir M. Part weight verification between simulation and experiment of plastic part in injection moulding process. IOP Conference Series: Materials Science and Engineering2016.

[14] Ali MAM, Sani SSM. Warpage Analysis Verification Between Simulation And Experimental Of Dumbbell Plastic Part In The Injection Moulding Process. Science International (Lahore). 2014;26:1575-79.

[15] Vishnuvarthanan M, Rajesh PR, Ilangovan S. Optimization of injection molding cycle time using moldflow analysis [J]. Middle-East Journal of Scientific Research. 2013;13:944-6.

[16] Amran M, Salmah S, Sanusi M, Yuhazri M, Mohamad N, Azam MA, et al. Surface Roughness Optimization in Drilling Process Using Response Surface Method (RSM). Jurnal Teknologi. 2014;66:29-35.

[17] Gheorghe O, Florin T, Vlad G, Gabriel D. Optimization of Micro Injection Molding of Polymeric Medical Devices Using Software Tools. Procedia Engineering. 2014;69:340-6.

[18] Min BH. A study on quality monitoring of injection-molded parts. Journal of Materials Processing Technology. 2003;136:1-6.

[19] Amran MA, Hadzley M, Amri S, Izamshah R, Hassan A, Samsi S, et al. Optimization of Gate, Runner and Sprue in Two-Plate Family Plastic Injection Mould. AIP Conference Proceedings: AIP; 2010. p. 309-13.

[20] King D, Tansey T. Alternative materials for rapid prototyping. Journal of Materials Processing Technology. 2002;121:313-7.

[21] Rodriguez J, Crouch C, Guenther B, VanEeuwen L, DeMenter J. In: Latin American and Caribbean Conference for Engineering and Technology (LACCEI'2014) July 22 - 24. Guayaquil, Ecuador; 2014.

[22] Mohd A, Noorfa I, Rosidah J, Mohd H, Yuhazri Y, Abdul R, et al. Comparison between star and linear runner layout of family plastic injection mold. ARPN Journal of Engineering and Applied Sciences. 2015;10:6263-68.

[23] Characterization and failure analysis of plastics: ASM International, The Materials Information Society, USA; 2003. 
[24] Kaushish JP. Manufacturing Processes. New Delhi: PHI learning Private Limited; 2010.

[25] Dey S, Chakraborty S. A study on the machinability of some metal alloys using grey TOPSIS method. Decision Science Letters. 2016;5:31-44.

[26] Mohd AA, Siti S, Zulkeflee, Pay JL, Mohd RM, Raja I, et al. Effect of different coolant medium on warpage deflection using moldflow insight analysis. 2015. p. 42-6.

[27] Akshay H, Naiju CD, Mukund NJ, Izabela N. Redesign of an in-market food processor for manufacturing cost reduction using DFMA methodology. Production \& Manufacturing Research. 2016;4:209-27. 